\title{
CITRONELLA ESSENTIAL OIL IN THE CONTROL AND ACTIVATION OF COFFEE PLANTS DEFENSE RESPONSE AGAINST RUST AND BROWN EYE SPOT
}

\author{
Óleo essencial de citronela no controle e na ativação de respostas \\ de defesa do cafeeiro contra a ferrugem e cercosporiose
}

\author{
Ricardo Borges Pereira1, Gilvaine Ciavareli Lucas², Fabiano José Perina², \\ Pedro Martins Ribeiro Júnior², EduardoAlves²
}

\begin{abstract}
The rust and brown eye spot are the main coffee diseases. The losses are due to intense defoliation of plants, which has reduced its production and longevity. The brown eye spot also occurs in fruits, with negative effects on the beverage quality. Some essential oils have presented promising results in the control of plant diseases, as an alternative to the use of fungicides. The objective of this study was to evaluate citronella essential oil in the control of rust and brown eye spot and in the activation of coffee plants defense responses. Twelve-month-old plants were sprayed with citronella oil $1000 \mu \mathrm{L} \mathrm{L}^{-1}$, acibenzolar-S-methyl $200 \mathrm{mg} \mathrm{L}^{-1}$ and tebuconazole fungicide $200 \mathrm{mg} \mathrm{L}^{-1}$. Plants were inoculated with Hemileia vastatrix and Cercospora coffeicola seven days later. The application was repeated after 30 days. Plants with five months were sprayed with the same treatments to assess the induced defense responses. Citronella oil controlled rust and brown eye spot with efficiencies of $47.2 \%$ and $29.7 \%$, respectively, while tebuconazole presented control of $96.5 \%$ and $90.5 \%$, respectively. Acibenzolar-S-methyl reduced brown eye spot by $55.9 \%$ and showed no significant control of rust. Citronella oil increased peroxidase and chitinase activities in five months coffee plants 336, and 24 and 336 hours after spraying, respectively. Acibenzolar-S-methyl increased peroxidase, chitinase and $\beta-1,3$-glucanase activities 192,288 and 336; 24 and; 240 hours after spraying, respectively. The treatments did not increase accumulation of phenols, but a significant increase in lignin was observed in plants sprayed with citronella oil.
\end{abstract}

Index terms: Hemileia vastatrix, Cercospora coffeicola, Cymbopogon nardus, induced resistance, alternative control of plant disease.

\section{RESUMO}

A ferrugem e a cercosporiose são as principais doenças de cafeeiro. Os prejuízos se devem a intensa desfolha das plantas que têm sua produção e longevidade reduzidas. A cercosporiose também ocorre nos frutos, com reflexos negativos na qualidade da bebida. Alguns óleos essenciais têm apresentado resultados promissores no controle de doenças em plantas, em alternativa ao uso de fungicidas. Neste trabalho, objetivou-se avaliar o óleo essencial de citronela no controle da ferrugem e cercosporiose e na ativação de respostas de defesa em cafeeiro. Plantas com 12 meses foram pulverizadas com o óleo de citronela $1.000 \mu \mathrm{L} \mathrm{L}^{-1}$, acibenzolar-S-metil $200 \mathrm{mg} \mathrm{L}^{-1}$ e fungicida tebuconazole $200 \mathrm{mg} \mathrm{L}^{-1}$ e inoculadas com Hemileia vastatrix e Cercospora coffeicola sete dias após. Repetiu-se a aplicação após 30 dias. Plantas com cinco meses foram pulverizadas com os mesmos tratamentos para avaliar as respostas de defesa induzidas. O óleo de citronela controlou a ferrugem e a cercosporiose com eficácias de $47.2 \%$ e $29,7 \%$, respectivamente, enquanto tebuconazole apresentou controles de $96,5 \%$ e $90,5 \%$, respectivamente. Acibenzolar-S-metil reduziram em 55,9\% a cercosporiose da ferrugem e não apresentou controle significativo da ferrugem. O óleo de citronela aumentou as atividades de peroxidase e quitinase em mudas de cafeeiro 336 e; 24 e 336 horas após pulverização, respectivamente. Acibenzolar-S-metil aumentou as atividades de peroxidase, quitinase e $\beta$-1,3-glucanase 192, 288 e 336 e; 24 e; 240 horas após pulverização, respectivamente. Os tratamentos não promoveram aumento de fenóis, mas aumento significativo no teor de lignina foi observado em plantas pulverizadas com óleo de citronela.

Termos para indexação: Hemileia vastatrix, Cercospora coffeicola, Cymbopogon nardus, indução de resistência, controle alternativo de doenças de plantas.

(Received in june 1, 2012 and approved in july 3, 2012)

\section{INTRODUCTION}

Coffee rust, caused by Hemileia vastatrix Berk $\& \mathrm{Br}$., is the most destructive disease of coffee. It can cause damages in trees and reduces yields by causing premature drop of infected leaves. Coffee rust has caused devastating losses in all coffee-producing regions in Brazil (AGRIOS, 2005), where environmental conditions are favorable to disease, yield losses can reach $10 \%$ or even $50 \%$ of the yields (ZAMBOLIM; VALE; ZAMBOLIM, 2005).

${ }^{1}$ Empresa Brasileira de Pesquisa Agropecuária/Embrapa Hortaliças - Centro Nacional de Pesquisa de Hortaliças - BR 060 - Km 09 - Cx. P. 218 70359970 - Gama - DF - Brasil - ricardobp@cnph.embrapa.br

2Universidade Federal de Lavras/UFLA - Departamento de Fitopatologia/DFP - Lavras - MG - Brasil

Ciênc. agrotec., Lavras, v. 36, n. 4, p. 383-390, jul./ago., 2012 
Brown eye spot, caused by Cercospora coffeicola Berk \& Cooke, is another economically important coffee disease in Brazil. The pathogen infects the plants in the nursery and also those at the production stage, affecting leaves and coffee cherries, predisposing them to infection by other pathogens (ZAMBOLIM; VALE; ZAMBOLIM, 2005). It causes their premature fall and accelerates maturation, increasing the amount of hollow and poorly shaped grains, resulting in losses in yield and quality of the beverage (POZZA, 2008).

Several measures can be used for the control of rust and brown eye spot, always seeking to combine efficiency with environmental and safety aspects of the applicator. Commonly, the control of these diseases is performed by the application of copper fungicides and systemic. However, the use of fungicides over time can cause the degradation of natural resources, problems of poisoning of applicators, increased risks of residues in fruits, as well as the emergence of resistant races of the pathogen (AGRIOS, 2005).

The induction of plant resistance to pathogens constitutes a promising strategy to control diseases. Once induced by an elicitor(s), the plant's natural defense system is activated, preventing the penetration and subsequent colonization of the pathogen in the tissue. The plant defense system includes a combination of physical and biochemical changes: the former include lignification, stiffening of the cell wall and formation of papillae (EBRAHIM; SINGH, 2011); and the latter comprise oxidative burst, phytoalexin accumulation and activation of pathogenesis-related proteins (PRPs), such as chitinases, $\beta$-1,3-glucanases and peroxidases (DURRANT; DONG, 2004). Resistance is expressed at the site of pathogen attack and systemically in uninfected parts of the plant, depending on the time interval between the application of the elicitor and the pathogen inoculation. Its duration may be a few days to weeks or persist throughout the life cycle of plant, becoming a constitutive defense (HEIL; BALDWIN, 2002). This activation can be achieved by treatment with biotic agents: avirulent forms of pathogens, incompatible races, in certain circumstances by virulent forms of pathogens, essential oils, plant and fungal extracts (SCHWAN-ESTRADA; STANGARLIN, 2005) or abiotic agents: acibenzolar-S-methyl (EBRAHIM; SINGH, 2011).

With advances in research, the existence has been noted of a large number of secondary compounds in medicinal plants that are able to activate the plants' defense system against various pathogens such as $C$. coffeicola (PEREIRA et al., 2008) and H. vastatrix in coffee (PEREIRA et al., 2012), Alternaria sesami (Kawamura) Mohanty and Behera in sesame (GULERIA; KUMAR, 2006), Drechslera graminea (Rabenh.) Shoemaker in barley (PAUL; SHARMA, 2002) and Rhizoctonia solani Kühn and Xanthomonas oryzae pv. oryzae (Ishiyama) Swings et al. in rice (KAGALE et al., 2004) and Xanthomonas vesicatoria (ex Doidge) Vauterin et al. in tomato (LUCAS et al., 2012).

Recently, Pereira et al., (2012) investigated the potential of citronella essential oil and others in control of coffee rust in different cultivars of coffee. The authors observed that essential oils had a direct toxic effect on urediniospores of $H$. vastatrix. However the mechanism of action of the oils was not fully elucidated. Given the need for investigation in relation to the elicitor activity of essential oils, the objective of this study was to assess the potential of citronella essential oil in the control of rust and brown eye spot and in the activation of coffee plants defense responses.

\section{MATERIAL AND METHODS}

The trials were conducted in the period from January 2009 to July 2010 at the Federal University of Lavras (Lavras, Minas Gerais State, Brazil).

To evaluating the efficiency of citronella essential oil in the control of rust and brown eye spot in coffee seedlings, seeds of coffee cultivar Mundo Novo 379/19 were sown in trays containing substrate composed of expanded vermiculite, organic materials, macro-and micronutrients. At five months of age (three/four pairs of true leaves) the plants were transplanted to polystyrene bags containing 3.0 L of the same substrate, until reaching 12 months of age. The plants were maintained in a greenhouse during the whole experimental period, with daytime and night-time average temperatures of $30^{\circ} \mathrm{C}$ and $22^{\circ} \mathrm{C}$, respectively, where they were periodically irrigated and fertilized as needed.

Two experiments were conducted concomitantly, one with each pathogen. Based on results of the efficiency from the preliminary trials, the citronella essential oil (Cymbopogon nardus (L.) Rendle) was selected. It was acquired from Professor Accorsi Medicinal Plants ${ }^{\circledR}$ (Piracicaba, São Paulo State, Brazil, site: www.profaccorsi.com.br) and tested at a concentration of $1000 \mu \mathrm{L} \mathrm{L}^{-1}$. Acibenzolar-S-methyl 200 $\mathrm{mg} \mathrm{L}^{-1}$, (resistance induction standard), fungicide tebuconazole $200 \mathrm{mg} \mathrm{L}^{-1}$, distilled water (control) and milk powder $10 \mathrm{~g} \mathrm{~L}^{-1}$, used as a natural emulsifier in the citronella oil treatment, were also evaluated in the experiments. 
The inoculums of the pathogens were obtained by collecting naturally infected coffee plant leaves in the field. Urediniospores of $H$. vastatrix were immediately removed from the leaves using a soft bristle brush, while leaves infected with brown eye spot were put in a damp chamber for three days. After this, the conidia produced were removed using a soft bristle brush moistened in distilled water, and the suspension was filtered in cheesecloth. For inoculation, the suspension of urediniospores of $H$. vastatrix and conidia of $C$. coffeicola were prepared at a concentration of $0.5 \mathrm{~g} \mathrm{~L}^{-1}$ and $1.5 \times 10^{4}$ conidia $\mathrm{mL}^{-1}$, respectively, in distilled water containing Tween 80 $(0.025 \%)$.

At 12 month old, the coffee plants were sprayed with the treatments until dripping, using a manual spray. After 30 days, these treatments were repeated. Seven days after the first application, the plants were inoculated with the pathogens. Soon afterwards, plants inoculated with $H$. vastatrix were placed in a moisture chamber, in the dark, for 60 hours, while those inoculated with $C$. coffeicola were maintained in a moisture chamber for 14 hours. The experiment was conducted in a randomized block design, with four repetitions, and the plot was composed of six plants. Five evaluations were carried out, starting from the $30^{\text {th }}$ day after inoculation, at 11-day intervals, according to the diagrammatic scale for rust (AZEVEDO, 1997) and brown eye spot (CUSTÓDIO et al., 2011). Soon afterwards, the areas under the severity progress curve of rust and brown eye spot were calculated, according to Shaner and Finney (1977), and the control percentages were calculated.

With the objective of evaluating defense responses induced in coffee by citronella oil, five-month-old plants, obtained as described above, were cultivated in trays and kept in the greenhouse. Citronella essential oil at a concentration of $1000 \mu \mathrm{L} \mathrm{L}^{-1}$, acibenzolar-S-methyl $200 \mathrm{mg}$ $\mathrm{L}^{-1}$ and distilled water (control) were all assessed. The plants were sprayed once with the treatments until runoff, using a manual spray. A randomized block design with three replications was used and experimental units consisting of one pot containing four plants.

For the quantification of pathogenesis-related proteins (peroxidases, chitinases and $\beta$-1,3-glucanases), all true leaves of plants were harvested at eight different times, 24, 72, 120, 168, 192, 240, 288 and 336 hours after spraying (has). For the quantification of total soluble phenols and lignin content a single harvest was performed 336 has. The leaves were collected and immediately frozen in liquid nitrogen for further analysis.

To prepare the protein extract, fresh leaf material $(1.0 \mathrm{~g})$ from treated and untreated coffee plants was homogenized for five minutes with pestle and mortar in 10 $\mathrm{mL}$ of ice-cold $50 \mathrm{mM}$ sodium acetate buffer $\mathrm{pH}$ 5.2, containing 0.1 mM EDTA. After filtration in cheesecloth, the homogenate was centrifuged at $12000 \mathrm{~g}$ for 15 minutes, and the supernatant (crude extract) was used as the source of enzymes. All the steps were carried out at $0-4^{\circ} \mathrm{C}$. Protein content of the crude extracts was determined using the Bradford (1976) protein assay, with bovine serum albumin (BSA) as a standard.

The activity of guaiacol peroxidase (POX; EC 1.11.1.7) was determined by adding $25 \mu \mathrm{L}$ of enzyme extract adjusted to $2.0 \mathrm{~mL}$ of a solution containing sodium acetate $50 \mathrm{mM} \mathrm{pH}$ 5.2, guaiacol $20 \mathrm{mM}$ and hydrogen peroxide 20 $\mathrm{mM}$. After incubation at $30^{\circ} \mathrm{C}$ for 10 minutes, absorbance was measured at $480 \mathrm{~nm}$ (URBANEK; KUZNIAKGEBAROWSKA; HERKA, 1991). One unit of POX was expressed as a variation of $\mathrm{OD}_{480}$ per 1.0 milligram of soluble protein per minute $\left(\ddot{\mathrm{A}}_{480 \mathrm{~mm}} \mathrm{mg} \mathrm{P}^{-1} \mathrm{~min}^{-1}\right)$. Assays were done in triplicate.

The activity of chitinase (CHI; EC 3.2.1.14) was determined by adding $70 \mu \mathrm{L}$ of enzymatic extract to the solution with $130 \mu \mathrm{L}$ of sodium acetate $50 \mathrm{mM} \mathrm{pH} 5.2$ and $60 \mu \mathrm{L}$ of CM-Chitin-RBV $\left(2.0 \mathrm{mg} \mathrm{mL}^{-1}\right)$, a specific substrate for chitinase supplied by Loewe Biochemica $\mathrm{GmbH}$, in a 96-well microplate, with a capacity of $350 \mu \mathrm{L}$. After incubation at $35^{\circ} \mathrm{C}$ for $80 \mathrm{~min}$, samples were acidified with $50 \mathrm{~mL}$ of $\mathrm{HCl} 0.5 \mathrm{~N}$, cooled in an ice bath for $10 \mathrm{~min}$ and centrifuged ( $1450 \mathrm{~g}$ for 10 minutes). An aliquot of $210 \mu \mathrm{L}$ of the supernatant of each sample was transferred to a new microplate to take readings at $492 \mathrm{~nm}$ in an EIA-compatible player (WIRTH; WOLF, 1990). Assays were done in triplicate.

The activity of $\beta$-1,3-glucanase (GLU; EC 3.2.1.6) was measured using a method similar to that used to measure chitinase, replacing the substrate with $\mathrm{CM}$ Curdlan-RBB (4.0 mg mL $\left.{ }^{-1}\right)$ and adjusting the aliquot of enzyme extract to $100 \mu \mathrm{L}$ (reducing the volume of acetate buffer to adjust the final volume to $310 \mu \mathrm{L}$ per well). To promote the hydrolytic action of $\beta$-1,3-glucanase, we adopted an incubation time of $35^{\circ} \mathrm{C}$ for 100 minutes. The samples were then photometrically measured with a 620 $n m$ filter in an EIA reader (WIRTH; WOLF, 1990). Assays were done in triplicate.

Lignin content was determined by testing with thioglycolic acid (TGA), where $0.2 \mathrm{~g}$ of foliar tissues were incubated in acetone $(85 \%)$ for 48 hours and centrifuged at $12000 \mathrm{~g}$ for five minutes. The supernatant (methanol extract) was transferred to new micro-centrifuge tube, in which the total soluble phenolic compounds were determined. The precipitate was dried and incubated with $5.0 \mathrm{~mL}$ of thioglycolic acid in $\mathrm{HCl} 2 \mathrm{~N}$ 1:10 (v/v) for four 
hours. The samples were centrifuged at $12000 \mathrm{~g}$ for 10 minutes and the supernatants transferred to new tubes where they received $200 \mu \mathrm{L}$ of $\mathrm{HCl} 10 \mathrm{~N}$. After an ice bath for four hours and being centrifuged at $12000 \mathrm{~g}$ for 10 minutes, the precipitate was homogenized in $5.0 \mathrm{~mL}$ of $\mathrm{NaOH} 0.5 \mathrm{~N}$ and absorbance was measured at $280 \mathrm{~nm}$. The amount of TGA derivatives (acid-soluble lignin) formed was measured by comparison with a standard curve $(0.01$ - $0.1 \mathrm{mg} \mathrm{mL}^{-1}$ of ether 2-hydroxypropyl) and the values expressed in micrograms of lignin per milligram fresh material (ug mg-1 MF). Assays were done in triplicate.

For the determination of total soluble phenols, 150 $\mu \mathrm{L}$ aliquots of the methanol extract were mixed with $150 \mu \mathrm{L}$ of Folin-Ciocalteau $0.25 \mathrm{~N}$ for five minutes and then homogenized with $150 \mu \mathrm{L}$ of $\mathrm{Na}_{2} \mathrm{CO}_{3} 1.0 \mathrm{M}$ for 10 minutes, followed by dilution with $1.0 \mathrm{~mL}$ of ultrapure water at room temperature for one hour. The absorbance values of the reaction were determined at $725 \mathrm{~nm}$ in a spectrophotometer and the curve was calculated based on catechol. The phenolic compounds are expressed as $\mu \mathrm{g}$ of catechol per milligram of dry weight (SPANOS; WROLSTAD, 1990). Assays were done in triplicate.

Statistical analyses were conducted using the Sisvar (v. 4.5) statistical software.

\section{RESULTS AND DISCUSSION}

In the experiment conducted in the greenhouse, no phytotoxicity symptom due to the application of the citronella essential oil on coffee plants was observed. Applications of tebuconazole fungicide decreased rust severity by $96.5 \%$, followed by citronella essential oil, which controlled $47.2 \%$ (Figure 1A). Applications of acibenzolar-S-methyl did not promote a significant control of rust, and neither did applications of powdered milk.

With respect to brown eye spot, it was found that application of tebuconazole fungicide reduced the severity of the disease by $90.5 \%$, followed by acibenzolar-S-methyl and citronella essential oil, with controls of $55.9 \%$ and $29.7 \%$, respectively (Figure 1B). Applications of powdered milk did not promote the control of brown eye spot.

Recent studies have confirmed the efficiency of citronella essential oil in the control of diseases. Pereira et al., (2011) observed that citronella oil at $1000 \mu \mathrm{L} \mathrm{L}^{-1}$ decreased brown eye spot severity by $43.08 \%$ and $29.62 \%$ on Catucaí and Mundo Novo cultivars, respectively. In Catuaí, Mundo Novo and Catucaí cultivars the same oil reduced the rust severity by $32.7 \%, 42.2 \%$ and $77.2 \%$, respectively (Pereira et al., 2012). The efficiency of citronella essential oil also was reported by Lima et al., (2008) in the control of ramulosis (Colletotrichum gossypii South var. cephalosporioides S.A. Costa) in cotton.

Regarding the induced defense responses, it was observed that Mundo Novo cultivar plants sprayed with acibenzolar-S-methyl presented an increase in peroxidase (POX) activity 192, 288 e 336 hours after spraying (has) (Figure 2A), and plants sprayed with citronella essential oil presented an increase in POX activity 336 has (Figure 2B). With respect to chitinase (CHI), it was found that plants sprayed with acibenzolar-S-methyl and citronella essential oil presented a significant increase in the $\mathrm{CHI}$ activity only
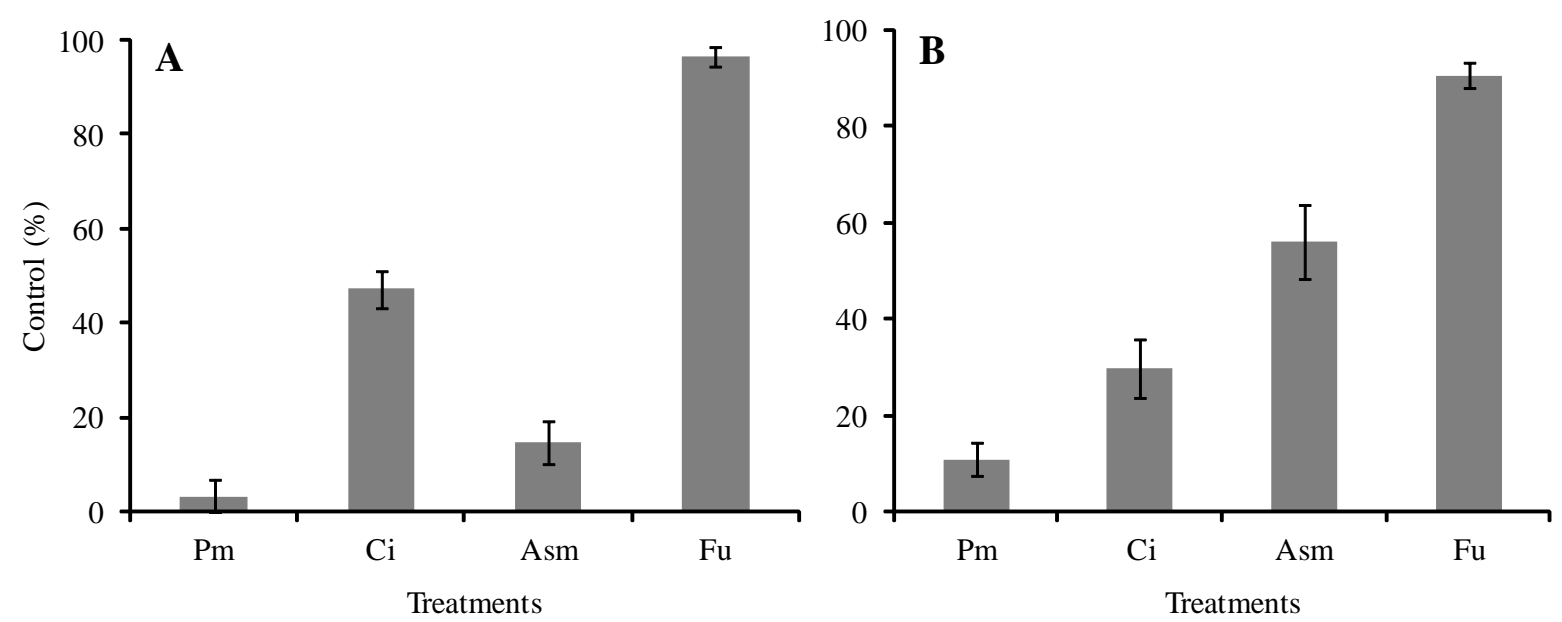

Figure 1 - Percent control of leaf rust (A) and brown eye spot (B) in coffee plants in relation to control treatment, 81 days after spraying with citronella essential oil (Ci) at concentration of $1000 \mu \mathrm{LL}^{-1}$, acibenzolar-S-methyl (Asm) $200 \mathrm{mg} \mathrm{L}^{1}$, tebuconazol fungicide $(\mathrm{Fu}) 200 \mu \mathrm{L} \mathrm{L}^{-1}$ and powdered milk $(\mathrm{Pm}) 10 \mathrm{~g} \mathrm{~L}^{-1}$. Error bars represent the standard deviation of the mean. 
at 24 has (Figure 2C and D). Though, plants sprayed with citronella oil also an increase in CHI activity 336 has. With respect to $\beta$-1,3-glucanase (GLU), it was found that plants treated with acibenzolar-S-methyl showed a significant increase in activity at 240 has (Figure 2E). Plants treated with citronella essential oil showed no significant increases in GLU activity compared to control (Figure 2F).
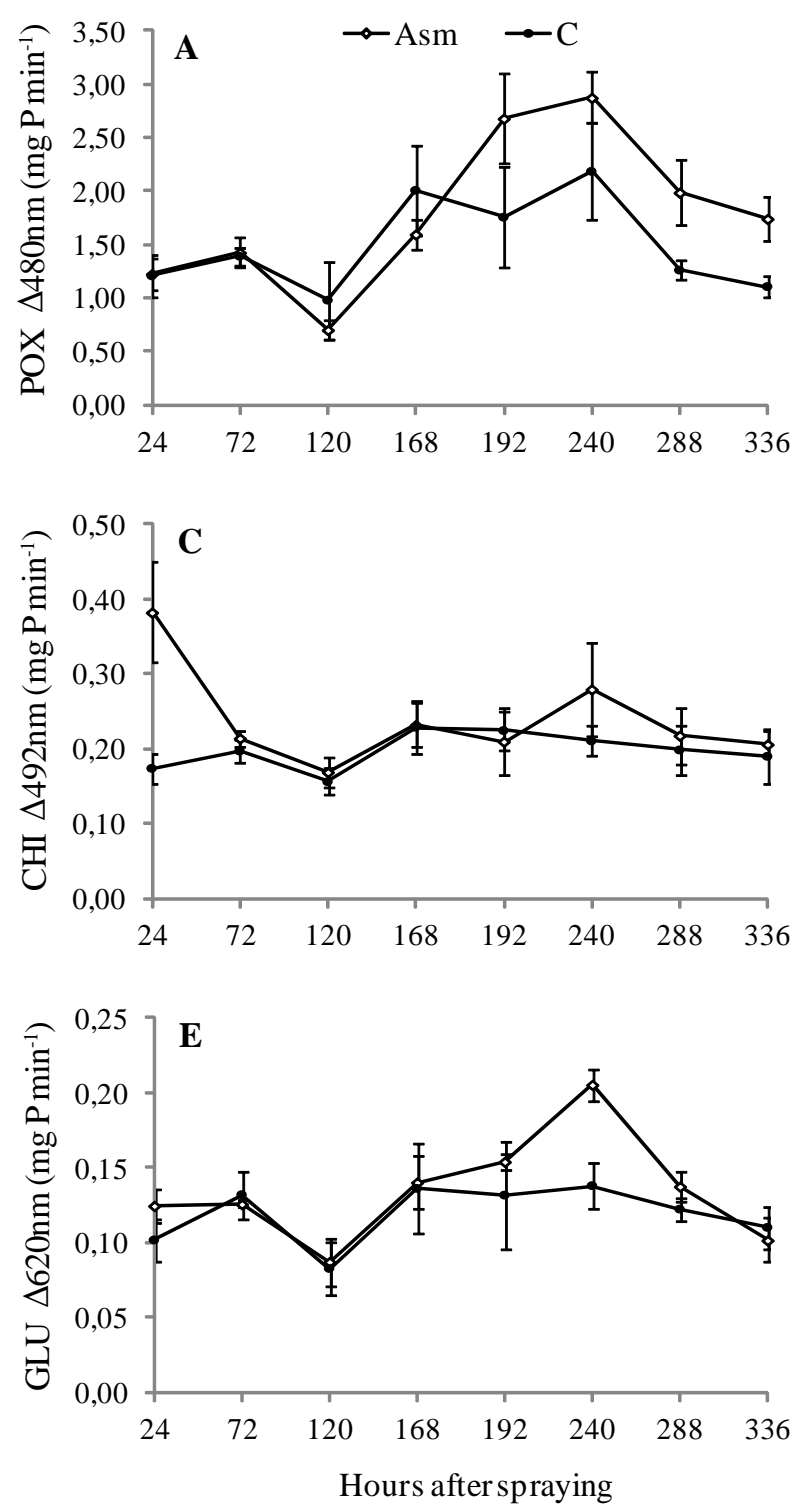

Plants treated with citronella essential oil and acibenzolar-S-methyl showed no significant differences in the accumulation of total soluble phenolics compared to the control 14 days after treatment (Figure 3). However, a significant increase in levels of soluble lignin was observed in coffee plants treated with citronella essential oil.
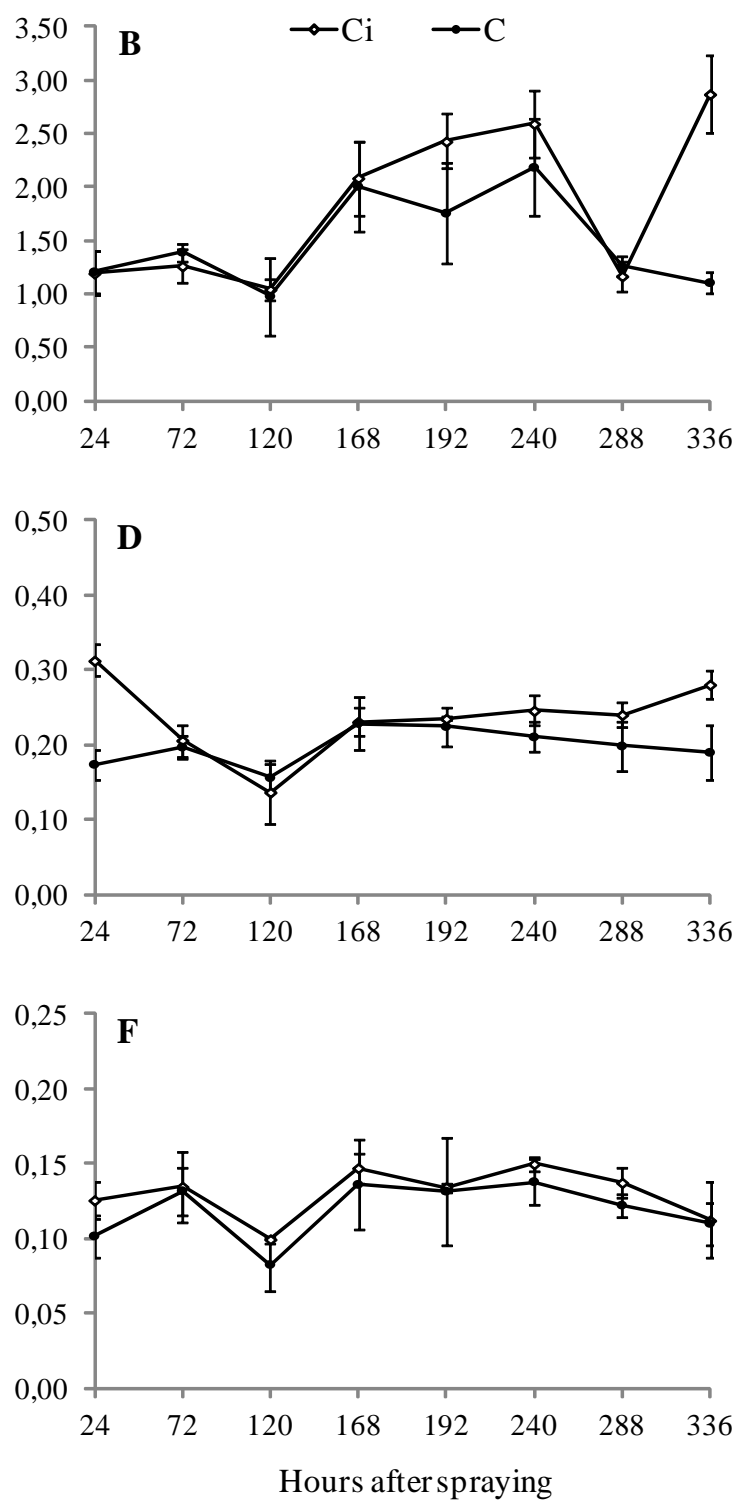

Figure 2 - POX (A and B), CHI (C and D) and GLU (E and F) activities in leaves of coffee seedlings after being treated with acibenzolar-S-methyl (Asm) $200 \mathrm{mg} \mathrm{L}^{1}$, citronella essential oils (Ci) $1000 \mu \mathrm{L} \mathrm{L}^{-1}$ and distilled water (C). Error bars represent the standard deviation of the mean from three independent biological experiments. 


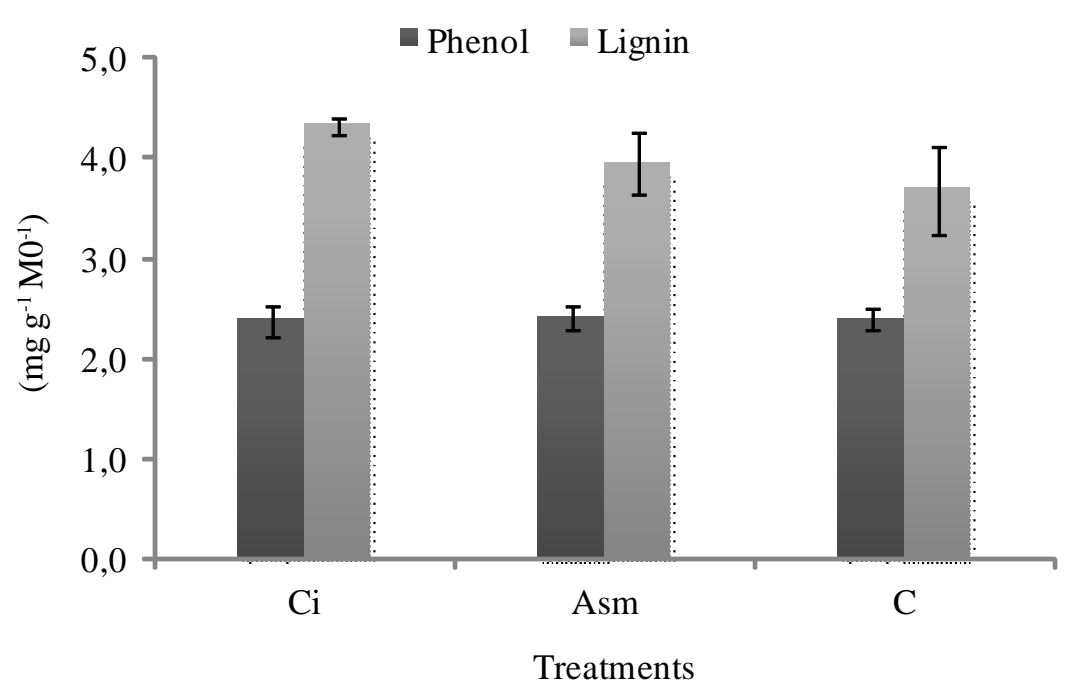

Figure 3 - Accumulation of total soluble phenolics and lignin 14 days after being treated with citronella essential oils (Ci) $1000 \mu \mathrm{L} \mathrm{L}^{-1}$, acibenzolar-S-methyl (Asm) $200 \mathrm{mg} \mathrm{L}^{1}$ and distilled water (C). Error bars represent the standard deviation of the mean.

Although few studies present the quantification of defense enzymes in coffee plants sprayed with essential oils. For instance, Pereira et al., (2008) found increased activity of peroxidases in coffee plants sprayed with thyme essential oil and challenged with $C$. coffeicola seven and eleven days after application. Also, some similar results have been shown in other pathosystems. In tomato plants, Lucas et al., (2012) found increased activity of peroxidases, chitinase and $\beta$-1,3-glucanase, and cell wall lignification in plants sprayed with clove essential oil and challenged with $X$. vesicatoria.

Studies have demonstrated that compounds present in essential oils, when in direct contact with the microorganism, can cause morphological changes in the hyphae, vacuolization and disorganization of the cytoplasm, rupture of plasma and mitochondria membranes and other organelles as well as changes in cell permeability and the flow of its constituents (AMARAL; BARA, 2005; RASOOLI; REZAEI; ALLAMEH, 2006). Recently, some of these effects, such as cellular disorganization and vacuolization, were observed in urediniospores of $H$. vastatrix (PEREIRA et al., 2012) and conidia of $C$. coffeicola (PEREIRA et al., 2008) exposed to citronella essential oil. Billerbeck et al., (2001) and Helal et al., (2007) also reported that the hyphae walls of Aspergillus niger Van Tieghem and AAspergillus flavus Link, respectively, disappeared in some regions after treatment with citronella essential oil.
Based on the results obtained in this study, it appears that the action of the citronella essential oil is not restricted to toxic effect on the structures of pathogens. This essential oil also contributes indirectly to control the disease by activation plant defense system, which was confirmed by increase in PRPs activities, such as POX, $\mathrm{CHI}$ and GLU, and accumulation of phenolic compounds (phenol and lignin) after spraying. This activation, beyond promoting protection against infection by $H$. vastatrix and C. coffeicola, promotes protection against invasion by other pathogens of the culture, because is increases the overall resistance of the plant.

Based on the results obtained, it is believed that citronella essential oils act directly on pathogens and activate defense response in coffee, reducing the infection rate of the pathogen and, consequently, the diseases severity. The alternative use of essential oils has the main purpose of reducing the use of pesticides which, over time, cause irreversible damage to human health and the environment. Thus, the use of citronella essential oil, along with other control strategies used in the integrated management of diseases, can provide satisfactory results in reducing diseases in coffee, especially in organic coffee production fields.

\section{CONCLUSION}

Citronella essential oil promotes partial control of rust and brown eye spot in coffee plant and activates the 
plants defense system, providing significant increases in POX and CHI activities, as well as lignin accumulation in coffee leaves 336 hours after spraying.

\section{ACKNOWLEDGEMENTS}

The authors thank the Conselho Nacional de Desenvolvimento Científico e Tecnológico (CNPq) for the doctoral scholarship to the first author and productivity grant for the last author the Fundação de Amparo à Pesquisa do Estado de Minas Gerais (FAPEMIG CAG PPM-00308-11 and APQ-02616-12) for financial support given to the Laboratório de Microscopia Eletrônica e Análise Ultraestrutural of the Universidade Federal de Lavras and to this study.

\section{REFERENCES}

AGRIOS, G.N. Plant pathology. 5th ed. New York: Academic, 2005. 922p.

AMARAL, M.F.Z.J.; BARA, M.T.F. Avaliação da atividade antifúngica de extratos de plantas sobre o crescimento de fitopatógenos. Revista Eletrônica de Farmácia, Goiânia, v. 2, n. 2, p. 5-8, maio/jun. 2005.

AZEVEDO, L.A.S. Manual de quantificação de doenças de plantas. São Paulo: Novartis, 1997. 114p.

BILLERBECK, V.G. de et al. Effects of Cymbopogon nardus (L.) W. Watson essential oil on the growth and morphogenesis of Aspergillus niger. Canadian Journal of Microbiology, Ottawa, v. 47, n. 1, p. 9-17, Jan. 2001.

BRADFORD, M.M. A rapid and sensitive method for the quantification of microgram quantities of protein utilizing the principle of protein-dye binding. Analytical

Biochemistry, New York, v. 72, n. 1-2, p. 248-254, May 1976.

CUSTÓDIO, A.A. de P. et al. Comparison and validation of diagrammatic scales for brown eye spots in coffee tree leaves. Ciência e Agrotecnologia, Lavras, v. 35, n. 6, p. 1067-1076, nov./dez. 2011.

DURRANT, W.E.; DONG, X. Systemic acquired resistance. Annual Review of Phytopathology, Palo Alto, v. 42, n. 3, p. 185-209, Mar. 2004.

EBRAHIM, S.; SINGH, K.U. Pathogenesis related (PR) proteins in plant defense mechanism. In: MÉNDEZVILAS, A. (Ed.) Science against microbial pathogens: communicating current research and technological advances. Extremadura: Formatex Research Center, v. 1, 2011, p. 1043-1054.

GULERIA, S.; KUMAR, A. Azadirachta indica leaf extract induces resistance in sesame against Alternaria leaf spot disease. Journal of Cell and Molecular Biology, Ulakbim, v. 5, n. 2, p. 81-86, Jun. 2006.

HEIL, M.; BALDWIN, I.T. Fitness costs of induced resistance: emerging experimental support for a slippery concept. Trends in Plant Science, Oxford, v. 7, n. 1, p. 61-67, Feb. 2002.

HELAL, G.A. et al. Effects of Cymbopogon citratus L. essential oil on the growth, morphogenesis and aflatoxin production of Aspergillus flavus ML2-strain. Journal of Basic Microbiology, Berlin, v. 47, n. 1, p. 5-15, Feb. 2007.

KAGALE, S. et al. Antimicrobial activity and induction of systemic resistance in rice by leaf extract of Datura metel against Rhizoctonia solani and Xanthomonas oryzae pv. oryzae. Physiological and Molecular Plant Pathology, London, v. 65, n. 2, p. 91-100, Aug. 2004.

LIMA, W.G. et al. Citronella oil inhibits cotton ramulosis in controlled conditions. Pest Technology, Kagawa, v. 2, n. 1, p. 24-27, Apr. 2008.

LUCAS, G.C. et al. Indian clove essential oil in the control of tomato bacterial spot. Journal of Plant Pathology, London, v. 94, n. 2, p. 45-51, Feb. 2012.

PAUL, P.K.; SHARMA, P.D. Azadirachta indica leaf extract induces resistance in barley against leaf stripe disease. Physiological and Molecular Plant Pathology, London, v. 61, n. 1, p. 3-13, July 2002.

PEREIRA, R.B. et al. Extrato de casca de café, óleo essencial de tomilho e acibenzolar-S-metil no manejo da cercosporiose-do-cafeeiro. Pesquisa Agropecuária Brasileira, Brasília, v. 43, n. 10, p. 1287-1296, out. 2008.

PEREIRA, R.B. et al. Essential oils for rust control on coffee plants. Ciência e Agrotecnologia, Lavras, v. 33, n. 1, p. 16-24, jan./fev. 2012.

PEREIRA, R.B. et al. Potencial de óleos essenciais no controle da cercosporiose-do-cafeeiro. Ciência e Agrotecnologia, Lavras, v. 35, n. 1, p. 115-123, jan./fev. 2011. 
POZZA, E.A.A. Importância das doenças foliares do cafeeiro. In: NÚCLEO DEESTUDOS EM FITOPATOLOGIA. (Eds.). Manejo fitossanitário da cultura do cafeeiro. Brasília: Sociedade Brasileira de Fitopatologia, v. 1, p. 81-94, 2008

RASOOLI, I.; REZAEI, M.B.; ALLAMEH, A. Growth inhibition and morphological alterations of Aspergillus niger by essential oils from Thymus eriocalyx and Thymus x-porlock. Food Control, Vurrey, v. 17, n. 5, p. 359-364, May, 2006.

SCHWAN-ESTRADA, K.R.F.; STANGARLIN, J.R.

Extratos e óleos essenciais de plantas medicinais na indução de resistência. In: CAVALCANTI, L. et al. (Eds.). Indução de resistência em plantas a patógenos e insetos. Piracicaba: FEALQ, v. 1, p. 125-138. 2005

SHANER, G.; FINNEY, R.F. The effect of nitrogen fertilization on the expression of slow-mildewing resistance in knox wheat. Phytopathology, St. Paul, v. 67, n. 8, p. 1051-1056, Aug. 1977.
SPANOS, G.A.; WROLSTAD, R.E. Influence of processing and storage on the phenolic composition of Thompson seedless grape juice. Journal of Agricultural \& Food Chemistry, Washington, v. 38, n. 7, p. 1565-1571, Jul. 1990.

URBANEK, H.; KUZNIAK-GEBAROWSKA, E.; HERKA $\mathrm{H}$. Elicitation of defence responses in bean leaves by Botrytis cinerea polygalacturonase. Acta Physiologica Plantarum, Poland, v. 13, n. 1, p. 43-50. Jan. 1991.

WIRTH, S.J.; WOLF, G.A. Dye-labelled substrates for the assay and detection of chitinase and lysozyme activity. Journal of Microbiological Methods, Amsterdam, v. 12, n. 12, p. 197-205, Dec. 1990.

ZAMBOLIM, L.; VALE, F.X.R.; ZAMBOLIM, E.M. Doenças do cafeeiro (C. arabica e C. canephora). In: KIMATI, H. et al. (Eds.). Manual de Fitopatologia: doenças das plantas cultivadas. 4.ed. São Paulo: Agronômica Ceres, v. 2, p.165-180, 2005. 